\title{
Article \\ Effect of Temperature on Biobeneficiation of Bulk Copper-Nickel Concentrate with Thermoacidophilic Microbial Communities
}

\author{
Anna Panyushkina ${ }^{1}\left(\mathbb{D}\right.$, Natalya Fomchenko $^{1}\left(\mathbb{D}\right.$, Vladislav Babenko $^{2}\left(\mathbb{D}\right.$ and Maxim Muravyov ${ }^{1, *(\mathbb{C}}$ \\ 1 Winogradsky Institute of Microbiology, Research Centre "Fundamentals of Biotechnology", Russian \\ Academy of Sciences, Leninsky Ave., 33, Bld. 2, 119071 Moscow, Russia; zhuravleva-inmi@mail.ru (A.P.); \\ natalya.fomchenko@gmail.com (N.F.) \\ 2 Federal Research and Clinical Centre of Physical-Chemical Medicine, Federal Medical Biological Agency, \\ 119435 Moscow, Russia; daniorerio34@gmail.com \\ * Correspondence: maxmuravyov@inmi.ru; Tel.: +7-495-135-6596
}

Citation: Panyushkina, A.;

Fomchenko, N.; Babenko, V.;

Muravyov, M. Effect of Temperature

on Biobeneficiation of Bulk

Copper-Nickel Concentrate with

Thermoacidophilic Microbial

Communities. Metals 2021, 11, 1969.

https://doi.org/10.3390/met11121969

Academic Editor: Stefano Ubaldini

Received: 30 October 2021

Accepted: 3 December 2021

Published: 7 December 2021

Publisher's Note: MDPI stays neutral with regard to jurisdictional claims in published maps and institutional affiliations.

Copyright: (c) 2021 by the authors. Licensee MDPI, Basel, Switzerland. This article is an open access article distributed under the terms and conditions of the Creative Commons Attribution (CC BY) license (https:// creativecommons.org/licenses/by/ $4.0 /)$.

\begin{abstract}
Bioleaching of the bulk copper-nickel sulfide concentrate was proposed as a method to remove nickel from it and to obtain a concentrate containing copper as chalcopyrite. This approach is based on the different refractoriness of sulfide minerals in ferric sulfate solutions and oxidation by acidophilic microorganisms. The bulk concentrate contained $10.8 \%$ copper in the form of chalcopyrite $\left(\mathrm{CuFeS}_{2}\right)$ and $7.2 \%$ nickel that occurred in pentlandite $\left((\mathrm{Ni}, \mathrm{Fe})_{9} \mathrm{~S}_{8}\right)$ and violarite $\left(\mathrm{FeNi}_{2} \mathrm{~S}_{4}\right)$. Three microbial communities grown at 35,40 , and $50^{\circ} \mathrm{C}$ were used for bioleaching. The microbial community at $40^{\circ} \mathrm{C}$ was the most diverse in the genus and species composition. At all temperatures of the process, the key roles in bioleaching belonged to mixotrophic and heterotrophic acidophiles. The highest levels of nickel leaching of 97.2 and $96.3 \%$ were observed in the case of communities growing at 40 and $50{ }^{\circ} \mathrm{C}$, respectively. At the same time, the bioleach residue, which could be characterized as a marketable high-grade copper (chalcopyrite) concentrate, was obtained only at $40{ }^{\circ} \mathrm{C}$. This solid contained $15.6 \%$ copper and $0.54 \%$ nickel. Thus, the biobeneficiation of bulk sulfide concentrates can be a promising field of biohydrometallurgy.
\end{abstract}

Keywords: bulk concentrate; biobeneficiation; selective bioleaching; biohydrometallurgy; nickel dissolution; acidophilic microbial communities

\section{Introduction}

The beneficiation of bulk concentrates of nonferrous metals, such as copper-nickel and copper-zinc sulfide concentrates, is aimed at obtaining high-grade selective concentrates, which are of current importance for the metallurgical industry [1]. However, the selective separation of bulk concentrates is often difficult due to the textural and structural properties of raw materials. As a result of the difficulties of selective metal concentration, relatively simply produced bulk concentrates can circulate in flotation circuits for a long time [1,2].

To achieve selective metal leaching, environmentally sound cost-effective and easyto-use technologies are required. These technologies include biohydrometallurgical approaches (particularly, bioleaching/biooxidation) that are applied at industrial mining and metallurgical enterprises worldwide for the recovery of metals from sulfidic raw materials [3-6]. These bio-approaches are based on the activity of communities of acidophilic chemolithotrophic microorganisms that oxidize ferrous iron, elemental sulfur $\left(S^{0}\right)$, reduced inorganic sulfur compounds (RISCs), and sulfide minerals [7]. The significance of the application of biohydrometallurgy is associated with relatively low environmental hazards in comparison with conventional pyrometallurgical methods [8,9]. Biohydrometallurgy allows the processing of low-grade raw materials, products, and metallurgical wastes, with reduced emissions and discharges of toxic substances to air $[6,10]$. 
Low-grade copper ores (copper is mainly in secondary sulfides) and gold-bearing (pyrite-arsenopyrite and pyrite) ores are the best-studied raw materials involved in bioprocessing $[11,12]$. Chalcopyrite is one of the most refractory minerals in ferric sulfate solutions, which determines the low efficiency/intensity of biohydrometallurgical approaches used for chalcopyrite processing [13]. In that regard, the idea of selective mineral leaching, associated with chalcopyrite concentration in the solids, seems promising for the processing of refractory bulk concentrates [14]. The possibility of the selective removal of zinc from the copper-zinc concentrate during leaching with a ferric sulfate solution obtained with an acidophilic chemolithotrophic microbial community, as well as during bioleaching, has been previously reported [15-17]. The varying composition of minerals in the copper-zinc concentrate has shown that a higher chalcopyrite/sphalerite ratio improves the rate of the oxidation of sphalerite [18].

Polymetallic copper-nickel sulfide concentrates are also promising raw materials for biohydrometallurgy. They are characterized by the relatively simple nickel leaching from pentlandite and violarite, while chalcopyrite is highly stable in ferric solutions [19]. The following simplified equations [20,21] summarize the oxidation of chalcopyrite $\left(\mathrm{CuFe}_{2}\right)$, pentlandite $\left((\mathrm{Ni}, \mathrm{Fe})_{9} \mathrm{~S}_{8}\right)$, and violarite $\left(\mathrm{FeNi}_{2} \mathrm{~S}_{4}\right)$ during bioleaching:

$$
\begin{gathered}
\mathrm{CuFe}{ }_{2}+4 \mathrm{Fe}^{3+}=\mathrm{Cu}^{2+}+2 \mathrm{~S}^{0}+5 \mathrm{Fe}^{2+}, \\
2(\mathrm{Ni}, \mathrm{Fe})_{9} \mathrm{~S}_{8}+36 \mathrm{Fe}^{3+}=9 \mathrm{Ni}^{2+}+16 \mathrm{~S}^{0}+45 \mathrm{Fe}^{2+}, \\
\mathrm{FeNi}_{2} \mathrm{~S}_{4}+18 \mathrm{Fe}^{3+}+8 \mathrm{H}_{2} \mathrm{O}=2 \mathrm{Ni}^{2+}+2 \mathrm{SO}_{4}{ }^{2-}+2 \mathrm{~S}^{0}+19 \mathrm{Fe}^{2+}+16 \mathrm{H}^{+} .
\end{gathered}
$$

Microorganisms oxidize the reaction products:

$$
\begin{gathered}
2 \mathrm{~S}^{0}+2 \mathrm{H}_{2} \mathrm{O}+3 \mathrm{O}_{2}=2 \mathrm{H}_{2} \mathrm{SO}_{4}, \\
4 \mathrm{Fe}^{2+}+\mathrm{O}_{2}+4 \mathrm{H}^{+}=4 \mathrm{Fe}^{3+}+2 \mathrm{H}_{2} \mathrm{O} .
\end{gathered}
$$

Previous studies have indicated that sulfide nickel-containing concentrates could be leached using mesophilic bacteria [22]. Batch bioleaching of the nickel ore concentrate containing pentlandite as a major nickel-bearing mineral at $30^{\circ} \mathrm{C}$ has resulted in the copper, cobalt, and nickel extraction of $22.4,67.5$, and $76 \%$, respectively [22].

The study of the bioleaching of the violarite-pentlandite-chalcopyrite concentrate at $40{ }^{\circ} \mathrm{C}$ allowed the removal of nickel and the obtainment of a high-grade copper concentrate. Violarite has been shown to dissolve more rapidly than pentlandite during bioleaching of the copper-nickel concentrate, with higher rates of nickel sulfide dissolution at $40{ }^{\circ} \mathrm{C}$ as compared to $30^{\circ} \mathrm{C}$ [23]. At $40^{\circ} \mathrm{C}$, the community of microorganisms was dominated by bacteria of the species Leptospirillum (L.) ferriphilum and Acidithiobacillus (At.) caldus, as well as Sulfobacillus (S.) spp. and archaea of the genera Cuniculiplasma and Ferroplasma (Fr.) as minor components. After 22 days of the bioleaching, the efficiency of nickel leaching reached $67.6 \%\left(30^{\circ} \mathrm{C}\right)$ and $86.7 \%\left(40{ }^{\circ} \mathrm{C}\right)$, while the copper content in the bioleach residue increased by 2.7 and $5.7 \%$, respectively [23].

Thermophilic bioleaching of a low-grade copper-nickel concentrate at high temperatures $\left(65,70,72,73,74\right.$, and $\left.75^{\circ} \mathrm{C}\right)$ has also been compared [24]. The process at $70^{\circ} \mathrm{C}$ allowed the highest copper and nickel extractions of $95 \%$ and $99 \%$, respectively. More than $98 \%$ of nickel could be extracted at both 45 and $70{ }^{\circ} \mathrm{C}$; however, the kinetics of leaching was slower at the former temperature. While $95 \% \mathrm{Cu}$ extraction was shown at $70{ }^{\circ} \mathrm{C}$, the final copper extraction of only $74 \%$ could be obtained at $45^{\circ} \mathrm{C}$ [24].

Nevertheless, bioleaching of nickel-containing sulfidic raw materials has been significantly less studied than bioprocesses for copper and zinc extraction. Moreover, the roles of the members of the microbial communities, as well as microbial interactions during the biooxidation of raw materials containing nickel sulfides, are not entirely clear. The determination of the microbial diversity in the communities formed during the biooxidation of sulfidic copper-nickel raw materials, as well as the possible roles of the community members, are decisive in assessing whether the biohydrometallurgical approach is promising 
for particular raw materials under the selected conditions. Therefore, efficient bioleaching of metals from copper-nickel concentrates by microbial communities is of high importance from both the fundamental and practical standpoints. The industrial biooxidation of sulfide raw materials is usually associated with exothermal reactions leading to increased temperatures of the medium in bioreactors. In this research, we used thermoacidophilic microbial communities for the biobeneficiation of bulk copper-nickel concentrates for the first time.

The goal of this research was to study changes in solids composition depending on the temperature during bioleaching of the copper-nickel concentrate by thermoacidophilic microbial communities. In addition, this study aimed to choose the temperature that allows obtaining a residue considered a marketable copper (chalcopyrite) concentrate.

\section{Materials and Methods}

\subsection{Copper-Nickel Concentrate}

The bulk sulfide concentrate of the copper-nickel ore (Shanuch district, Kamchatka territory, Russia) flotation was the object of this study. The concentrate was composed of chalcopyrite, pentlandite, violarite, pyrrhotite, and pyrite. Quartz, chabazite, jarosite, plagioclase, chlorite, and albite were gangue minerals. The content of the main elements is shown in Table 1. Table 2 shows the content of sulfide minerals in the concentrate. The particle size of the concentrate was $\mathrm{d}_{80}<44 \mu \mathrm{m}$. The methods used for obtaining these data are provided in Section 2.5.

Table 1. Main element content (wt\%) in concentrate.

\begin{tabular}{cccccc}
\hline $\mathbf{C u}$ & $\mathbf{N i}$ & $\mathbf{F e}$ & $\mathbf{S}$ & $\mathbf{C a}$ & $\mathbf{S i}$ \\
\hline 10.8 & 7.2 & 21.8 & 26.5 & 0.96 & 18.0 \\
\hline
\end{tabular}

Table 2. Sulfide mineral content $(w t \%)$ in concentrate.

\begin{tabular}{ccccc}
\hline Chalcopyrite & Pentlandite & Violarite & Pyrrhotite & Pyrite \\
\hline 31 & 12 & 8 & 4 & 6 \\
\hline
\end{tabular}

\subsection{Microbial Communities and Cultivation Conditions}

For bioleaching experiments at 35,40 , and $50{ }^{\circ} \mathrm{C}$, three acidophilic microbial consortia were formed from the stirred-tank biotreatment of the waste containing zinc [25], as well as copper-zinc and copper-nickel concentrates [23]. The original community contained chemolithoautotrophic and mixotrophic strains of iron and sulfur oxidizers assigned to various species: At. caldus, At. thiooxidans, At. ferrooxidans, Fr. acidarmanus, Fr. acidiphilum, L. ferriphilum, Acidiplasma (Ad.) sp., S. thermosulfidooxidans and S. thermotolerans, as well as Acidibacillus (Ac.) sp. and Ferrimicrobium (Fm.) sp. The community was also composed of acidophilic heterotrophs: Alicyclobacillus (Al.) spp. and Acidiphilium (Ap.) multivorum [26], as well as the archaeon Cuniculiplasma sp. [25].

This original community was subsequently grown at 35,40 , and $50{ }^{\circ} \mathrm{C}$ to obtain inocula for bioreactor experiments. Flasks (culture medium, $900 \mathrm{~mL}$; inoculum, $100 \mathrm{~mL}$ ) were incubated for two days at 30,40, and $50{ }^{\circ} \mathrm{C}$ (Redline RI53 thermostats, Binder, Germany). The culture medium contained the following (g/L): $\left(\mathrm{NH}_{4}\right)_{2} \mathrm{SO}_{4}, 0.75 ; \mathrm{KCl}, 0.025$; $\mathrm{K}_{2} \mathrm{HPO}_{4} \cdot 3 \mathrm{H}_{2} \mathrm{O}, 0.125 ; \mathrm{MgSO}_{4} \cdot 7 \mathrm{H}_{2} \mathrm{O}, 0.125 ; \mathrm{Ca}\left(\mathrm{NO}_{3}\right)_{2} \cdot 4 \mathrm{H}_{2} \mathrm{O}, 0.0025 ; \mathrm{FeSO}_{4} \cdot 7 \mathrm{H}_{2} \mathrm{O}, 30.0 ; \mathrm{S}^{0}$, 10.0; yeast extract, 0.1 . The initial $\mathrm{pH}$ was adjusted to 1.6 with $5 \mathrm{M} \mathrm{H}_{2} \mathrm{SO}_{4}$. The experiments were carried out under the conditions of intensive aeration. The air was supplied at a flow rate of $1 \mathrm{v} /(\mathrm{v} \cdot \mathrm{min})$. The obtained solutions ( $\mathrm{pH} 1.3)$ contained microbial communities of acidophiles $\left(0.1 \times 10^{9}\right.$ cells $/ \mathrm{mL}$ at $50{ }^{\circ} \mathrm{C}$ and $0.8 \times 10^{9}$ cells $/ \mathrm{mL}$ at 35 and $\left.40{ }^{\circ} \mathrm{C}\right), \mathrm{Fe}^{3+}(6.0$, 5.9 , and $5.9 \mathrm{~g} / \mathrm{L}$ at 35,40 , and $50{ }^{\circ} \mathrm{C}$, respectively) and the unoxidized part of $\mathrm{S}^{0}$. These solutions were separated from the sulfur precipitates by filtration on paper filters and used for bioleaching processes. 


\subsection{Analysis of Microbial Community}

The structure of the original microbial consortia (inocula) grown at 35,40 , and $50{ }^{\circ} \mathrm{C}$, as well as microbial communities formed at the end of the process, were assessed by cell morphology using phase-contrast microscopy and metabarcoding using the 16S rRNA gene hypervariable region (V3-V4). To obtain biomass for metabarcoding analysis, a suspension was centrifuged $(100 \times g, 2 \mathrm{~min})$ to precipitate solids, and cell pellets were further collected by centrifugation $(5000 \times g, 15 \mathrm{~min})$ of the obtained supernatant. The biomass was sequentially washed by centrifugation $(10,000 \times g, 5 \mathrm{~min})$ with the iron-free $9 \mathrm{~K}$ medium First, the iron-free $9 \mathrm{~K}$ medium with $\mathrm{pH} 1.5$ was used to wash the biomass by centrifugation $(10,000 \times g, 5 \mathrm{~min})$. In the next step, the biomass was washed using the same medium but with a neutral $\mathrm{pH}$ [27]. Homogenization of the samples was carried out in a MagNA Lyser (Roche, Basel, Switzerland) device. DNA was extracted according to the standard protocol for MagNA Pure Bacteria Lysis Buffer (Roche, Basel, Switzerland). The 16S library preparation and sequencing were carried out according to Illumina protocol. Briefly, amplification of the extracted DNA with standard $16 \mathrm{~S}$ rRNA gene primers, complementary to the V3-V4 region and containing 5 '-Illumina adapter sequences, was performed. After that, individual amplicons were PCR-indexed and pooled. Sequencing of DNA libraries was carried out with a MiSeq instrument (Illumina, San Diego, CA, USA) and the Miseq reagent kit v3 (Illumina, San Diego, CA, USA). After demultiplexing was performed [28], reads containing the $16 \mathrm{~S}$ rRNA primer sequences were filtered out with the CLC Genomics Workbench version 10.0 (Qiagen, Redwood City, CA, USA). To choose operational taxonomic units (OTU) and to carry out the taxon-based assignment, the QIIME open-source software pipeline [29] and the Silva132 database [30] were used. All parameters were set to default values. The analysis included $\approx 12,000-30,000$ fragments (an average length, 449 nucleotides).

To identify microorganisms at the species level, analysis of the similarity of nucleotide sequences of the $16 \mathrm{~S}$ rRNA gene fragments was carried out using the Nucleotide Basic Local Alignment Search Tool (BLAST; Bethesda, MD, USA, https:/ / blast.ncbi.nlm.nih.gov/ Blast.cgi, accessed on 25 October 2021).

\subsection{Bioleaching Procedure}

Batch bioleaching of the concentrate was carried out in a $2.0 \mathrm{~L}$ bioreactor (working volume, $1.0 \mathrm{~L}$ ). Before the beginning of the bioleaching, the bioreactor containing $10 \mathrm{~g}$ of the solid sample was supplemented with $1.0 \mathrm{~L}$ of inoculum containing $\approx 0.1 \times 10^{9}$ cells $/ \mathrm{mL}$ at $50{ }^{\circ} \mathrm{C}$ and $0.8 \times 10^{9}$ cells $/ \mathrm{mL}$ at 35 and $40{ }^{\circ} \mathrm{C}$ (the pulp density, $1 \%(w / v)$ ). Thus, the inoculum volume was $100 \%(v / v)$. The initial $\mathrm{pH}$ value was $1.1-1.2$. The $\mathrm{pH}$ of the pulp was monitored, and concentrated sulfuric acid was added when necessary to maintain the $\mathrm{pH}$ values. The experiments were carried out at a stirring speed of $500 \mathrm{rpm}$ using an overhead 8-blade Rushton turbine impeller, with aeration $(4 \mathrm{v} /(\mathrm{v} \cdot \mathrm{min}))$. Once a day, distilled water was added to the bioreactor to compensate for evaporation losses. At the end of bioleaching, the pulp from the bioreactor was centrifuged at $2000 \times g \mathrm{rpm}$ for $5 \mathrm{~min}$, and the residue was washed three times with distilled water and dried to constant weight.

\subsection{Analytical Methods}

The relative number of cells in $1 \mathrm{~mL}$ was determined by ten-fold dilutions and subsequent direct counting in the Goryaev chamber using a Mikmed-2 microscope equipped with a phase contrast device (LOMO, Moscow, Russia).

The values of the $\mathrm{pH}$ and redox potential were measured with a $\mathrm{pH}-150 \mathrm{MI} \mathrm{pH}$ metermillivoltmeter (Izmeritelnaya tekhnika, Moscow, Russia). The concentration of the $\mathrm{Fe}^{3+}$ ions in the liquid phase was determined by complexometric titration [31]. The same method was used to determine the total concentration of iron after the reaction with ammonium peroxydisulfate. The concentration of ferrous iron ions was calculated as the difference between the total and ferric iron. Flame atomic absorption spectroscopy (FAAS) (Perkin 
Elmer 3100, PerkinElmer, Waltham, MA, USA) was used to determine the concentrations of copper and nickel.

Solids were analyzed by a wet chemical method, using 1:3 concentrated nitric acid/ concentrated hydrochloric acid at the boiling temperature of the mixture. This analysis was followed by FAAS for metals and gravimetric analysis with $\mathrm{BaCl}_{2}$ for sulfur [32]. The mineralogical composition of solids was determined with X-ray diffraction microscopy (DRON-2 diffractometer, Burevestnik, St. Petersburg, Russia). The Rietveld refinement of the XRD patterns was used to evaluate the relative mineral phase amounts [33]. For image acquisition, a reflected light optical microscopy (Olympus BX51 microscope, Olympus, Tokyo, Japan) was used. The microscope was set to operate using polarized reflected light. The samples of solids were mounted in polished sections embedded in epoxy resin.

According to the following equation, mass loss (wt \%) was calculated:

$$
\gamma=100-\frac{m_{r}}{m_{\text {in }}} \cdot 100
$$

where $m_{r}$ - the weight of bioleach residue $(\mathrm{g}) ; m_{i n}$ - the weight of the original sample $(\mathrm{g})$.

Metal recovery (wt \%) was calculated from the following equation:

$$
\varphi=\frac{C \cdot V}{10 \cdot \beta_{i n} \cdot m_{i n}},
$$

where $C$ is the metal concentration in pregnant leach solution $(\mathrm{mg} / \mathrm{L}) ; V$ is a solution volume $(\mathrm{L}) ; \beta_{\text {in }}$ is the metal content in the original sample $(\mathrm{wt} \%)$.

All experiments were carried out in duplicate. Statistical processing was performed using Microsoft Excel 2013. The standard deviation (SD) of the arithmetic mean was calculated, and the significance of the results was assessed using Student's $t$-test at the significance level $p \leq 0.1$.

\section{Results and Discussion}

\subsection{Pregnant Leach Solution Characteristics}

The physicochemical parameters of the liquid phase of the pulp were measured during the concentrate bioleaching. These were the $\mathrm{pH}$ value, the ambient redox potential, the concentration of ferrous and ferric iron, as well as the copper and nickel concentrations. Based on these values, the extraction of metals from solids was calculated. Figure 1 shows changes in the $\mathrm{pH}$ and redox potential values in different temperature modes. An abrupt increase in the $\mathrm{pH}$ value on the first day of the bioleaching required the addition of $1 \mathrm{~mL}$ of concentrated sulfuric acid for the processes at 35 and $50{ }^{\circ} \mathrm{C}$ and $2 \mathrm{~mL}$ at $40{ }^{\circ} \mathrm{C}$. The dissolution of gangue minerals could lead to an increase in $\mathrm{pH}$ according to the reaction:

$$
\mathrm{Fe}_{1-\mathrm{x}} \mathrm{S}+2(1-\mathrm{x}) \mathrm{H}^{+}=(1-\mathrm{x}) \mathrm{Fe}^{2+}+(1-\mathrm{x}) \mathrm{H}_{2} \mathrm{~S}+\mathrm{x} \mathrm{S}^{0} .
$$

In all cases, after sulfuric acid was added on the first day of bioleaching, the $\mathrm{pH}$ value remained relatively constant in the range of 1.1-1.2. This was due to the simultaneous microbial oxidation of ferrous iron increasing $\mathrm{pH}$, and elemental sulfur oxidation producing sulfuric acid. The redox potential value decreased sharply on the first day of the process due to the consumption of ferric iron for the oxidation of sulfide minerals according to Equations (1)-(3), as well as the following reaction:

$$
\mathrm{Fe}_{1-\mathrm{x}} \mathrm{S}+(2-2 \mathrm{x}) \mathrm{Fe}^{3+}=(3-3 \mathrm{x}) \mathrm{Fe}^{2+}+\mathrm{S}^{0}
$$

After that, it increased relatively rapidly, within 1-7 days, due to the microbial oxidation of ferrous iron (Equation (5)), and stabilized at the level of 860-911, 930-943, and $845 \mathrm{mV}$ (vs. standard hydrogen electrode (SHE)) at 35,40 , and $50{ }^{\circ} \mathrm{C}$, respectively. A lower value of the redox potential at $50{ }^{\circ} \mathrm{C}$ was due to the low concentration of ferric iron in the liquid phase of the pulp, as a result of its more pronounced precipitation in the form of 
jarosite (see Table 3). An increase in the temperature during the bioleaching of sulfidic raw materials is known to lead to a greater jarosite formation [34,35]. Changes in the ferrous and ferric iron concentrations in the liquid phase of the pulp at different temperatures (Figure 2) confirmed this conclusion. At all temperatures studied, the microbial communities oxidized ferrous iron completely and relatively rapidly. Beginning from the fourth day of bioleaching, the ferric iron concentration remained almost constant due to the low pulp density and relatively low iron content $(21.8 \mathrm{wt} \%)$ in the concentrate.
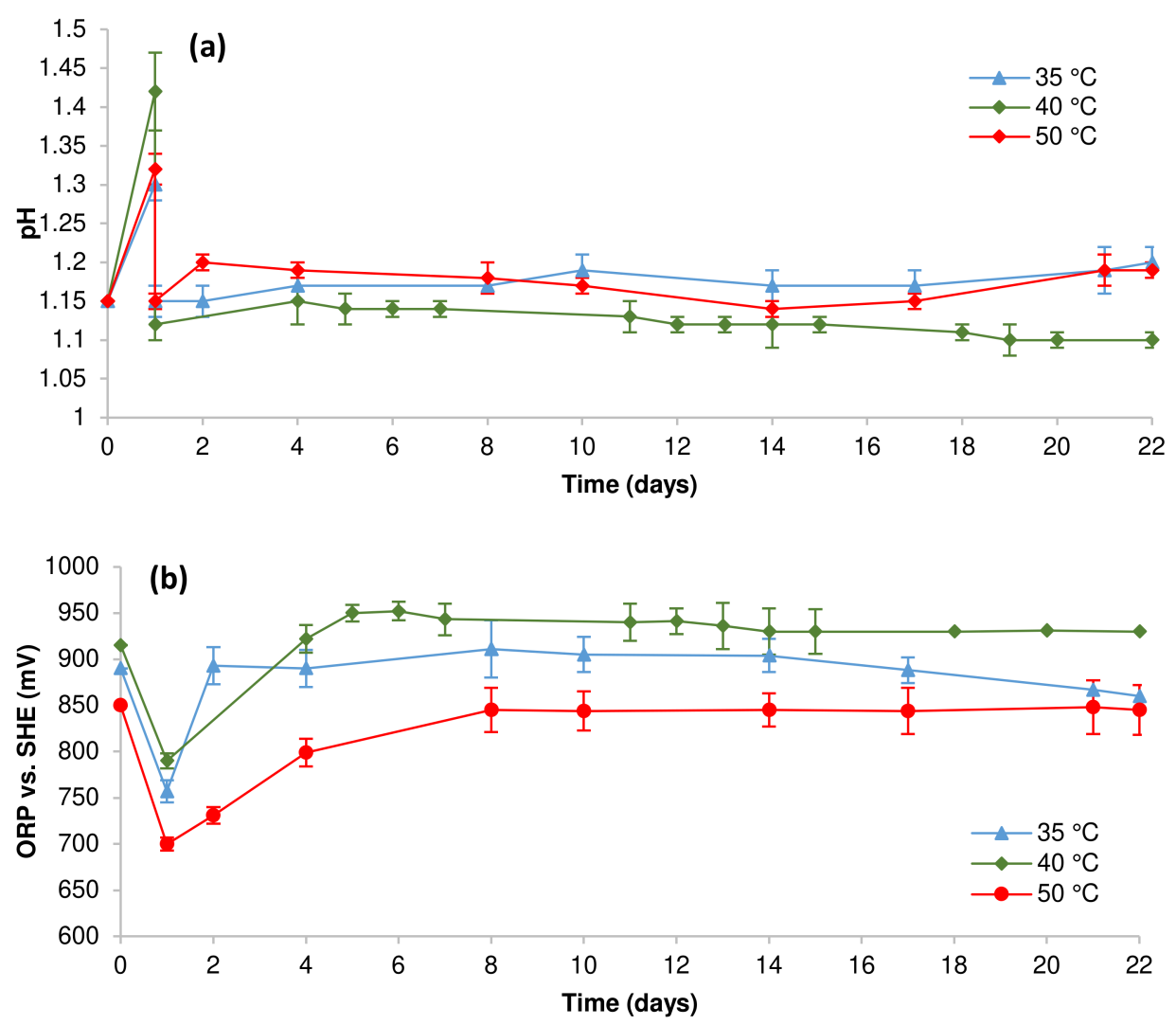

Figure 1. Values of (a) $\mathrm{pH}$ and (b) redox potential during stirred-tank bioleaching (pulp density, $1 \mathrm{wt} \%$ ).

Table 3. Content of main minerals in the bioleach residues (pulp density, $1 \mathrm{wt} \%$; duration, 22 days).

\begin{tabular}{|c|c|c|c|c|c|c|c|}
\hline \multirow{2}{*}{$\begin{array}{l}\text { Temperature at } \\
\text { Bioleaching }\left({ }^{\circ} \mathrm{C}\right)\end{array}$} & \multicolumn{7}{|c|}{ Content (wt $\%$ ) } \\
\hline & Chalcopyrite & Pentlandite & Violarite & Pyrite & Pyrrhotite & Jarosite & Elemental Sulfur \\
\hline 35 & 35 & 2 & 0 & 2 & 0 & 25 & 1 \\
\hline 40 & 45 & traces & 0 & 1 & 0 & 17 & 1 \\
\hline 50 & 30 & traces & 0 & traces & 0 & 40 & 1 \\
\hline
\end{tabular}

Figure 3 shows the dissolution of nickel and copper during bioleaching of the concentrate at different temperatures. The lowest dissolution of nickel was recorded at $35^{\circ} \mathrm{C}$. At 40 and $50{ }^{\circ} \mathrm{C}$, the final nickel dissolution was close and reached 97.2 and $96.3 \mathrm{wt} \%$, respectively. The highest dissolution of copper was observed at $50{ }^{\circ} \mathrm{C}$. A greater dissolution of chalcopyrite (as well as other sulfide minerals) by thermotolerant and moderately thermophilic microorganisms in comparison with mesophiles is well known. Among other factors, it is caused by an increase in the rate of chemical reactions with increasing temperatures [36-38]. Moreover, an increase in the solubility of chalcopyrite in ferric sulfate solutions has been repeatedly shown at relatively low values of the redox potential [39-41]. Figure 2 indicates that the value of the redox potential was, on average, $100 \mathrm{mV}$ less during bioleaching of the concentrate at $50{ }^{\circ} \mathrm{C}$ than at $40{ }^{\circ} \mathrm{C}$. Choosing a more suitable temperature 
of these two and taking into account that the goal of bioleaching was to achieve the greatest removal of nickel and to obtain a high-grade copper concentrate as solids, a community growing at $40{ }^{\circ} \mathrm{C}$ should be selected.

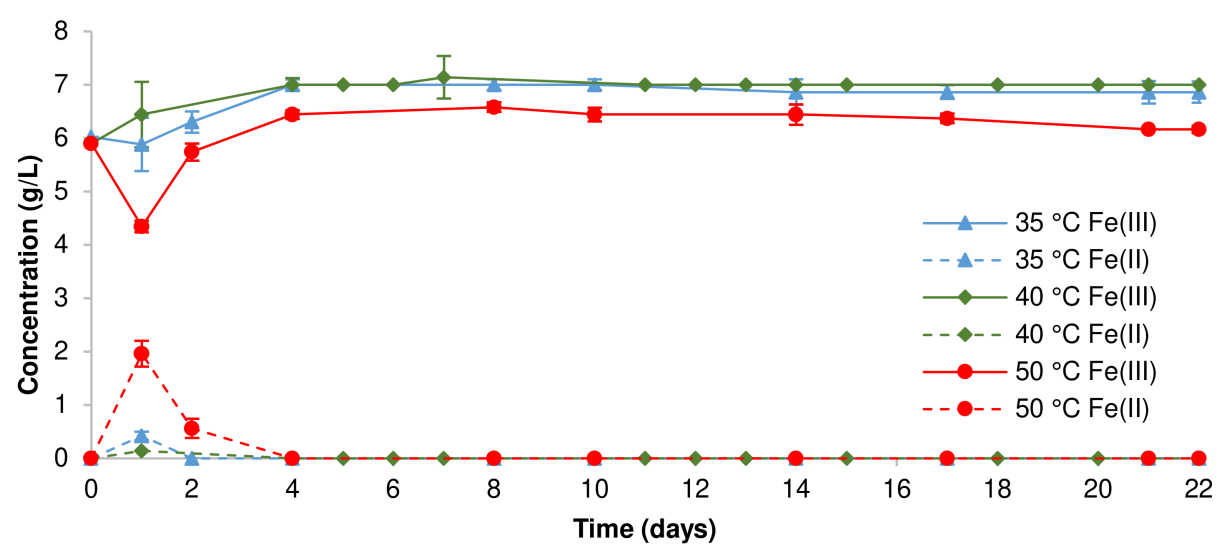

Figure 2. Ferric and ferrous iron concentration in the aqueous phase during stirred-tank bioleaching of the concentrate (pulp density, $1 \mathrm{wt} \%$ ).

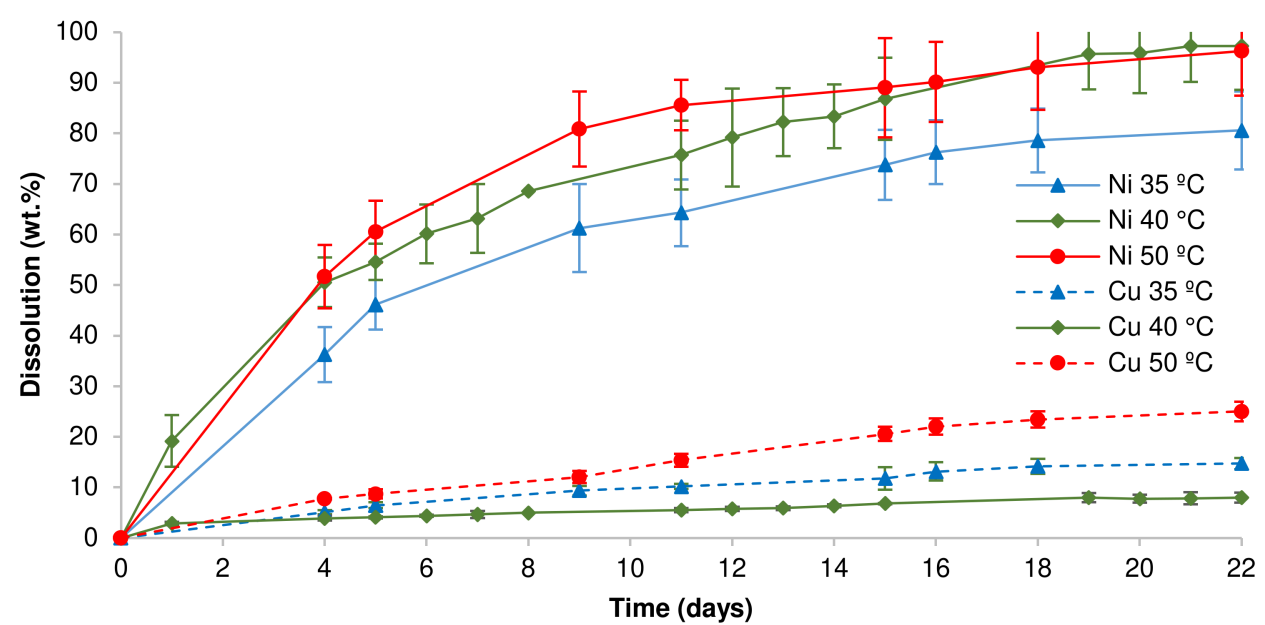

Figure 3. Rate of copper and nickel dissolution during stirred-tank bioleaching (pulp density, $1 \mathrm{wt} \%$ ).

\subsection{Solids Composition}

The solids obtained after 22 days of bioleaching of the copper-nickel concentrate were subjected to chemical and mineralogical analyses to determine their compositions. The results of powder X-ray diffraction and light microscopy of polished sections of solids in comparison with the original concentrate are shown in Figures 4 and 5, respectively. The calculations of the mineral contents are presented in Table 3. The content of the main elements in bioleach residues is shown in Table 4 . Analysis of the original concentrate composition indicated the presence of the following sulfide minerals: pentlandite, violarite, pyrrhotite, pyrite, and chalcopyrite. According to the data presented, pyrrhotite and violarite were almost completely removed from the concentrate during the bioleaching at all three temperatures. At $35^{\circ} \mathrm{C}$, a small amount of pentlandite was found in the solids, while it was almost completely dissolved at other temperatures. Pyrite was present in all three bioleach residues. However, its content was the highest in the solid obtained at $35^{\circ} \mathrm{C}$. These patterns agree with the refractoriness of sulfide minerals in ferric sulfate solutions due to the rest potential of the sulfide minerals [42]. Mason and Rice [43] have previously shown that the solubility of sulfide minerals during the bioleaching of nickel concentrate may be ranked in the following order: pyrrhotite $>$ violarite $>$ pyrite $>$ pentlandite $>$ chalcopyrite. 

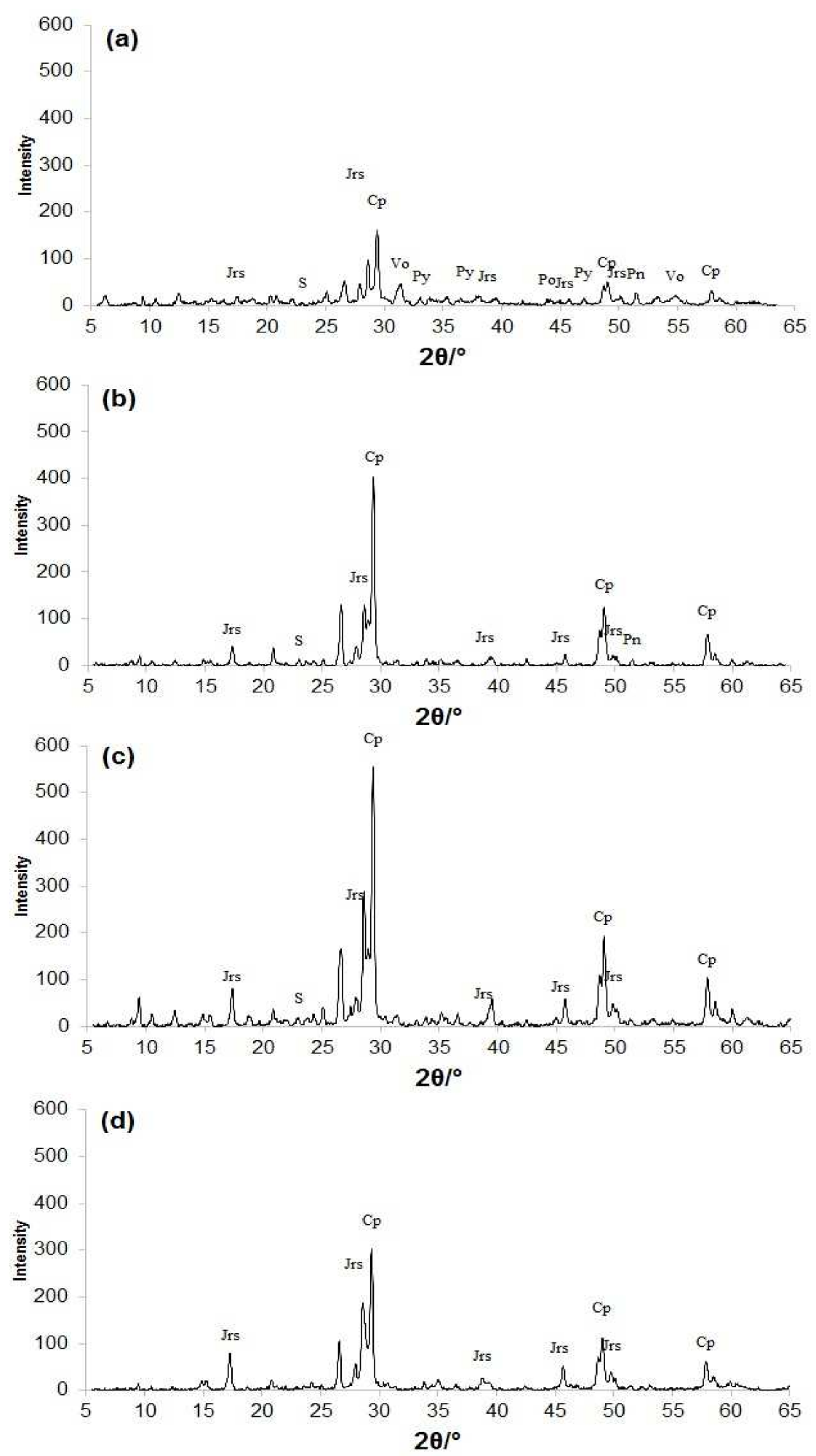

Figure 4. XRD patterns (a) of the original concentrate and bioleach residues at (b) 35, (c) 40, and (d) $50{ }^{\circ} \mathrm{C}$ (Pn, pentlandite; Vo, violarite; $\mathrm{Cp}$, chalcopyrite; Py, pyrite; Po, pyrrhotite; S, elemental sulfur; Jrs, jarosite). 

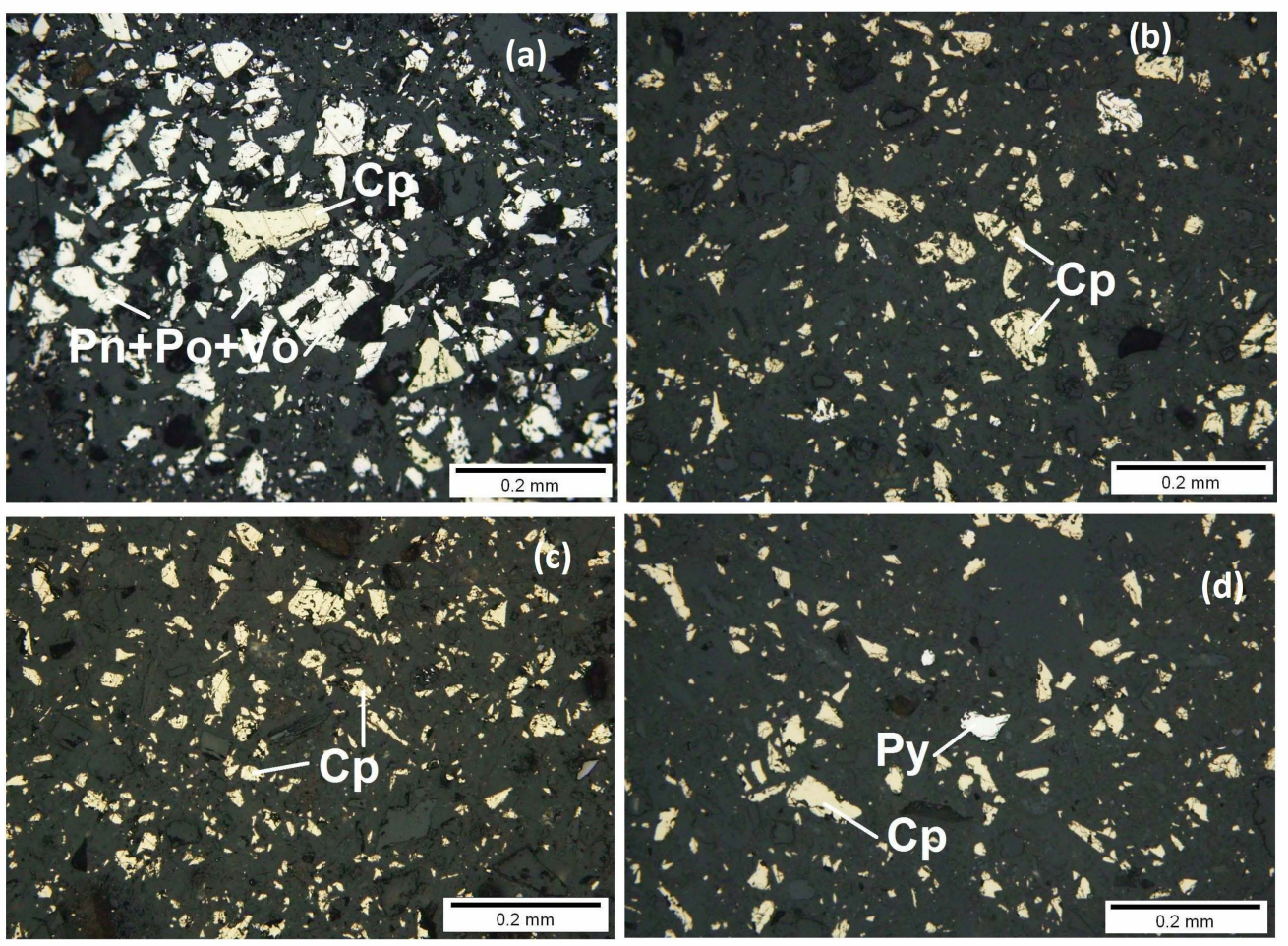

Figure 5. Optical micrographs of (a) the original concentrate and solids after their bioleaching at (b) 35, (c) 40, and (d) $50^{\circ} \mathrm{C}$, respectively (Pn, pentlandite; Vo, violarite; Cp, chalcopyrite; Py, pyrite; Po, pyrrhotite).

Table 4. Mass loss of concentrate during bioleaching and content of main elements in bioleach residues (pulp density, $1 \mathrm{wt} \%$; duration, 22 days).

\begin{tabular}{cccccc}
\hline \multirow{2}{*}{$\begin{array}{c}\text { Temperature at } \\
\text { Bioleaching }\left({ }^{\circ} \mathbf{C}\right)\end{array}$} & Mass Loss (wt \%) & \multicolumn{4}{c}{ Content (wt \%) } \\
\cline { 3 - 6 } & & $\mathbf{C u}$ & $\mathbf{N i}$ & $\mathbf{F e}$ & 20.2 \\
\hline 35 & 27 & 12.3 & 1.54 & 21.4 & 18.1 \\
40 & 40 & 15.6 & 0.54 & 19.8 & 20.6 \\
50 & 27 & 10.3 & 0.18 & 15.7 \\
\hline
\end{tabular}

In general, bioleach residues obtained with thermotolerant and moderately thermophilic microbial cultures at 40 and $50{ }^{\circ} \mathrm{C}$ contained mainly chalcopyrite, jarosite, quartz, and chabazite. In fact, these residues were copper concentrates. At the same time, according to the Russian Federation standard (GOST R 52998-2008), only the solid obtained at $40{ }^{\circ} \mathrm{C}$ was a high-grade copper concentrate, which contained $15.6 \mathrm{wt} \%$ copper.

\subsection{Microbial Community Structure}

The original microbial consortium was composed of acidophilic bacteria and archaea that were different in their phylogenetic position (see Section 2.2 and Table 5) and physiological characteristics. This community included sulfur- and iron-oxidizing microorganisms as well as heterotrophic bacteria and archaea, which showed active growth within the temperature range of $35-50{ }^{\circ} \mathrm{C}$. After subsequent culturing in the medium containing ferrous iron and elemental sulfur, certain changes in the community structure were recorded (Table 5). During 22 days of bioleaching, the cell populations were monitored using microscopy and metabarcoding analysis at the beginning and the end of the process. Although closely related microorganisms are usually not differentiated only based on the differences in the V3-V4 region, some bacterial and archaeal species were predicted due to the high variability of the V3-V4 regions within the corresponding genera [25]. 
Table 5. Structure of the microbial communities at the beginning and the end of the bioleaching of the concentrate at different temperatures.

\begin{tabular}{|c|c|c|c|c|c|c|c|}
\hline Species & $\begin{array}{c}\text { Original } \\
\text { consortium } 1\end{array}$ & $\begin{array}{l}\text { Inoculum } 2, \\
35^{\circ} \mathrm{C}\end{array}$ & $\begin{array}{c}\text { Final 3, } \\
35^{\circ} \mathrm{C}\end{array}$ & $\begin{array}{c}\text { Inoculum, } \\
40^{\circ} \mathrm{C}\end{array}$ & Final, $40^{\circ} \mathrm{C}$ & $\begin{array}{c}\text { Inoculum, } \\
50{ }^{\circ} \mathrm{C}\end{array}$ & Final, $50{ }^{\circ} \mathrm{C}$ \\
\hline At. ferrooxidans & +4 & $\mathrm{~N} / \mathrm{A}$ & $\mathrm{N} / \mathrm{A}$ & $\mathrm{N} / \mathrm{A}$ & $\mathrm{N} / \mathrm{A}$ & -5 & - \\
\hline At. thiooxidans & + & $\mathrm{N} / \mathrm{A}$ & $\mathrm{N} / \mathrm{A}$ & $\mathrm{N} / \mathrm{A}$ & $\mathrm{N} / \mathrm{A}$ & - & - \\
\hline At. caldus & + & $\mathrm{N} / \mathrm{A}$ & $\mathrm{N} / \mathrm{A}$ & $\mathrm{N} / \mathrm{A}$ & $\mathrm{N} / \mathrm{A}$ & - & - \\
\hline Acidithiobacillus spp. & + & + & + & + & + & - & - \\
\hline S. thermotolerans & + & + & + & + & + & + & + \\
\hline S. thermosulfidooxidans & + & - & - & + & + & + & + \\
\hline Al. tolerans & + & + & + & + & + & + & + \\
\hline Ac. ferrooxidans & + & - & - & + & + & - & - \\
\hline Fr. acidiphilum & + & + & + & + & - & - & - \\
\hline Fr. acidarmanus & + & - & - & - & - & - & - \\
\hline Acidiplasma sp. & + & - & - & - & - & + & + \\
\hline Cuniculiplasma sp. & + & - & - & + & - & - & - \\
\hline L. ferriphilum & + & + & - & + & + & - & - \\
\hline Ap. multivorum & + & - & - & - & - & - & - \\
\hline Fm. acidiphilium & + & - & - & + & - & - & - \\
\hline
\end{tabular}

${ }^{1}$ Original microbial consortium structure used to form subsequent original microbial communities at 35,40 , and $50{ }^{\circ} \mathrm{C}$. ${ }^{2}$ Original community structure in inocula grown at 35,40 , or $50{ }^{\circ} \mathrm{C} .{ }^{3}$ Structure of the communities at the end of the process (day 22$) .{ }^{4}+$, present. 5 -, absent. Abbreviations: N/A, not available; At. Acidithiobacillus; S. Sulfobacillus; Al. Alicyclobacillus; Ac. Acidibacillus; Ap. Acidiphilium; Fr. Ferroplasma; Fm. Ferrimicrobium.

While the initial cell numbers at 35 and $40{ }^{\circ} \mathrm{C}$ were similar $\left(0.8 \times 10^{9}\right.$ cells $\left./ \mathrm{mL}\right)$, the original microbial community was more diverse in genera at $40 \mathrm{C}$. At $50{ }^{\circ} \mathrm{C}$, the cell number was approximately one order of magnitude lower $\left(0.1 \times 10^{9}\right.$ cells $\left./ \mathrm{mL}\right)$, and the microbial diversity was the lowest among all three variants (Table 5). In the course of copper-nickel concentrate bioleaching at 35 and $40{ }^{\circ} \mathrm{C}$, the total cell numbers increased up to $2.5 \times 10^{9}$ cells $/ \mathrm{mL}$ during the first seven days of bioleaching, and this pattern did not change until the end of the process. At $50{ }^{\circ} \mathrm{C}$, the cell abundance increased until the last day of the process, reaching $3.0 \times 10^{8}$ cells $/ \mathrm{mL}$ after seven days of cultivation and $6.0 \times 10^{8}$ cells $/ \mathrm{mL}$ on day 22 . Such variations in microbial growth patterns are mainly due to the different microbial structures of the communities at these temperatures. At temperatures over $45{ }^{\circ} \mathrm{C}$, the most abundant sulfur-oxidizing and iron-oxidizing members, such as Acidithiobacillus spp. that reach the numbers of $>10^{9}$ cells $/ \mathrm{mL}$, are usually eliminated due to their temperature growth limit [7]. At the end of the process, communities formed at 35 and $40{ }^{\circ} \mathrm{C}$ included Acidithiobacillus spp., Sulfobacillus spp., and Alicyclobacillus spp.

It is noteworthy that metabarcoding analysis indicated the presence of Sulfobacillus spp. and Alicyclobacillus spp. at all temperatures studied (Table 5). Strains of different Sulfobacillus species are mixotrophic bacteria capable of both sulfur and iron oxidation in the presence of small amounts of organic substances in the temperature range of $20-60{ }^{\circ} \mathrm{C}$, with an optimum of $>35-55{ }^{\circ} \mathrm{C}[7,44]$. Except for $35{ }^{\circ} \mathrm{C}$, the genus Sulfobacillus in the microbial communities was represented by the species $S$. thermosulfidooxidans. Nucleotide sequences of the $16 \mathrm{~S}$ rRNA gene fragment showed $100 \%$ similarity with those of $S$. thermosulfidooxidans strains and only 99.1 and $98.7 \%$ similarity to other closest species: S. sibiricus and S. benefaciens, respectively. In contrast, another species, S. thermotolerans $(100 \%$ similarity to the type strain $S$. thermotolerans $\mathrm{Kr}^{\mathrm{T}}$, as well as other $S$. thermotolerans strains, and only $97.5 \%$ similarity to the second closest species $S$. thermosulfidooxidans), was identified at all temperatures: 35,40 , and $50{ }^{\circ} \mathrm{C}$. Previously, this species has been shown to play a crucial role in biotechnological processes and to possess high metabolic and resistance capacities $[25,44]$.

As mentioned above, in addition to Sulfobacillus spp., bacteria assigned to the genus Alicyclobacillus were also detected at all temperatures. Most Alicyclobacillus species are known to possess organoheterotrophic metabolism. However, Al. tolerans can grow heterotrophically or mixotrophically, oxidizing elemental sulfur, ferrous iron, and/or sulfide minerals in the presence of organic substances in the medium, with the optimum growth temperature of $37-42^{\circ} \mathrm{C}$ [45]. Most probably, it was this species that was present in 
the microbial communities in these bioleaching experiments. This conclusion was based on $100 \%$ similarity to nucleotide sequences of the $16 \mathrm{~S}$ rRNA gene fragments of $\mathrm{Al}$. tolerans strains, including the type strain $A$ l. tolerans $\mathrm{K} 1^{\mathrm{T}}$ [45] and another close strain $A$ l. tolerans PCG-3 [46], and only 93.8\% similarity to the second closest species Al. disulfidooxidans. Thus, in all communities, the genus Alicyclobacillus was represented by the species Al. tolerans characterized by mixotrophic/heterotrophic metabolism.

Iron-oxidizing bacteria Leptospirillum spp. (most probably, L. ferriphilum, according to the results of metabarcoding analysis) were identified in the original communities grown at 35 and $40{ }^{\circ} \mathrm{C}$. At $40{ }^{\circ} \mathrm{C}$, Leptospirillum cells reached $\approx 50 \%$ of the total microbial population at the beginning of cultivation, substantially decreasing in number in the course of the process due to the prevailing oxidation of sulfur by the community in the middle and at the end of the bioleaching. Moreover, at this temperature, the original microbial community and the community formed at the end of the bioleaching process showed the highest diversity and was also represented by facultatively chemolithoheterotrophic bacterium Acidibacillus sp. The latter was most probably related to the species Ac. ferrooxidans based on the nucleotide sequences of the 16S rRNA gene fragment, similarly to the data on the bioleaching of another copper-nickel concentrate at $40{ }^{\circ} \mathrm{C}$ [23]. Acidibacillus spp. belong to the phylum Firmicutes, which is well separated from Sulfobacillus and Alicyclobacillus spp. and capable of sulfur and/or ferrous iron oxidation [47]. At $40{ }^{\circ} \mathrm{C}$, a heterotrophic iron-oxidizing extremely acidophilic actinobacterium assigned to the genus Ferrimicrobium, Fm. acidiphilium [48], was also identified. Fm. acidiphilium is the only known species belonging to this genus. In addition to heterotrophic/mixotrophic Alicyclobacillus strains, another heterotrophic member of the community, archaeon Cuniculiplasma sp. [49], was also detected in the original community formed at $40{ }^{\circ} \mathrm{C}$. At $50{ }^{\circ} \mathrm{C}$, an iron-oxidizing archaeon Acidiplasma sp., which is known to oxidize ferrous iron at increased temperatures [50], was functioning in the community during bioleaching of the concentrate.

Thus, the microbial community at $40{ }^{\circ} \mathrm{C}$ (both the original one and the community formed at the end of the bioleaching process) was the most diverse in the genus and species composition. At the same time, the crucial roles in bioleaching belonged to mixotrophic and heterotrophic acidophiles at all temperatures of the bioleaching process. This result underlines the pivotal role of mixotrophs and the underestimated contribution of heterotrophic microorganisms that facilitate the growth of chemolithotrophic community members and oxidation of the concentrate components by them.

\section{Conclusions}

In this study, bioprocessing of the bulk copper-nickel concentrate with different thermoacidophilic microbial communities was compared at three different temperatures: 35 , 40 , and $50^{\circ} \mathrm{C}$. According to the results, the optimum temperature for copper-nickel concentrate bioleaching proved to be $40{ }^{\circ} \mathrm{C}$, at which a high-grade copper concentrate was obtained and nickel was almost completely leached. At increased temperature $\left(50{ }^{\circ} \mathrm{C}\right)$, the oxidation level of chalcopyrite was higher and yielded a decreased content of copper in the final solid. At a lower temperature $\left(35^{\circ} \mathrm{C}\right)$, relatively high content of nickel remained in the bioleach residue. Analysis of the microbial communities involved in the process indicated that the crucial roles in bioleaching belonged to mixotrophic and heterotrophic acidophiles. This result underlined an underestimated role of heterotrophic microorganisms that indirectly contributed to the efficiency of the bioprocess, facilitating the growth and oxidation of the concentrate components by other chemolithotrophic community members. Insights into the patterns of the biooxidation of nickel sulfidic minerals with acidophilic microbial communities in different modes of the process are the key issues to intensify the biohydrometallurgical treatment of nickel-containing raw materials. Such studies can increase the attractiveness of biotechnologies to industrialists and improve their commercial applications. 
Author Contributions: Conceptualization, M.M. and A.P.; methodology, M.M, A.P. and V.B.; validation, M.M. and A.P.; formal analysis, N.F.; investigation, M.M., A.P., N.F. and V.B.; data curation, M.M. and A.P.; writing — original draft preparation, M.M. and A.P.; writing—review and editing, M.M. and A.P.; visualization, M.M. and A.P.; supervision, A.P.; project administration, M.M.; funding acquisition, M.M. All authors have read and agreed to the published version of the manuscript.

Funding: This research was funded by Russian Science Foundation, grant number 21-14-00077.

Institutional Review Board Statement: Not applicable.

Informed Consent Statement: Not applicable.

Data Availability Statement: Not applicable.

Conflicts of Interest: The authors declare no conflict of interest. The funder had no role in the design of the study; in the collection, analyses, or interpretation of data; in the writing of the manuscript, or in the decision to publish the results.

\section{References}

1. Wills, B.A.; Finch, J.A. Wills' Mineral Processing Technology: An Introduction to the Practical Aspects of Ore Treatment and Mineral Recovery, 8th ed.; Butterworth-Heinemann: Oxford, UK, 2015.

2. Frias, C.; Sánchez, F.; Van Staden, P.; Milanovic, D.; Kolehmainen, E. The IntMet project provides innovative hydro and biohydroTechnologies to deal efficiently with polymetallic and complex suphide ores. In Proceedings of the IMPC 2018-29th International Mineral Processing Congress, Moscow, Russia, 17-21 September 2018; Canadian Institute of Mining, Metallurgy and Petroleum: Montreal, QC, Canada, 2019; pp. 2690-2699.

3. Kaksonen, A.H.; Deng, X.; Bohu, T.; Zea, L.; Khaleque, H.N.; Gumulya, Y.; Boxall, N.J.; Morris, C.; Cheng, K.Y. Prospective directions for biohydrometallurgy. Hydrometallurgy 2020, 195, 105376. [CrossRef]

4. Yin, S.-H.; Chen, W.; Fan, X.-L.; Liu, J.-M.; Wu, L.-B. Review and prospects of bioleaching in the Chinese mining industry. Int. J. Miner. Metall. Mater. 2021, 28, 1397-1412. [CrossRef]

5. Kaksonen, A.H.; Lakaniemi, A.-M.; Tuovinen, O.H. Acid and ferric sulfate bioleaching of uranium ores: A review. J. Clean. Prod. 2020, 264, 121586. [CrossRef]

6. Li, J.; Yang, H.; Tong, L.; Sand, W. Some aspects of industrial heap bioleaching technology: From basics to practice. Miner. Process. Extr. Metall. Rev. 2021, 1-9. [CrossRef]

7. Kondrat'eva, T.F.; Pivovarova, T.A.; Tsaplina, I.A.; Fomchenko, N.V.; Zhuravleva, A.E.; Murav'ev, M.I.; Melamud, V.S.; Bulayev, A.G. Diversity of the communities of acidophilic chemolithotrophic microorganisms in natural and technogenic ecosystems. Microbiology 2012, 81, 1-24. [CrossRef]

8. Pathak, A.; Morrison, L.; Healy, M.G. Catalytic potential of selected metal ions for bioleaching, and potential techno-economic and environmental issues: A critical review. Biores. Technol. 2017, 229, 211-221. [CrossRef]

9. Potysz, A.; Pędziwiatr, A.; Hedwig, S.; Lenz, M. Bioleaching and toxicity of metallurgical wastes. J. Environ. Chem. Eng. 2020, 8, 104450. [CrossRef]

10. Fomchenko, N.V.; Muravyov, M.I. Two-step biohydrometallurgical technology of copper-zinc concentrate processing as an opportunity to reduce negative impacts on the environment. J. Environ. Manag. 2018, 226, 270-277. [CrossRef]

11. Mahmoud, A.; Cezac, P.; Hoadley, A.F.A.; Contamine, F.; D’Hugues, P. A review of sulfide minerals microbially assisted leaching in stirred tank reactors. Int. Biodeterior. Biodegradation 2017, 119, 118-146. [CrossRef]

12. Kaksonen, A.H.; Mudunuru, B.M.; Hackl, R. The role of microorganisms in gold processing and recovery: A review. Hydrometallurgy 2014, 142, 70-83. [CrossRef]

13. Zhao, H.; Zhang, Y.; Zhang, X.; Qian, L.; Sun, M.; Yang, Y.; Zhang, Y.; Wang, J.; Kim, H.; Qiu, G. The dissolution and passivation mechanism of chalcopyrite in bioleaching: An overview. Miner. Eng. 2019, 136, 140-154. [CrossRef]

14. Harvey, T.J.; Yen, W.T.; Paterson, J.G. Selective zinc extraction from complex copper/zinc sulphide concentrates by pressure oxidation. Miner. Eng. 1992, 5, 975-992. [CrossRef]

15. Fomchenko, N.V.; Muravyov, M.I. Selective leaching of zinc from copper-zinc concentrate. Appl. Biochem. Microbiol. 2017, 53, 73-77. [CrossRef]

16. Fomchenko, N.; Uvarova, T.; Muravyov, M. Effect of mineral composition of sulfidic polymetallic concentrates on non-ferrous metals bioleaching. Miner. Eng. 2019, 138,1-6. [CrossRef]

17. Muravyov, M.I.; Panyushkina, A.E.; Melamud, V.S.; Bulaev, A.G.; Fomchenko, N.V. Ferric leaching of bulk sulfidic concentrates with biologically generated solution. Appl. Biochem. Microbiol. 2021, 57, 493-499. [CrossRef]

18. Fomchenko, N.V.; Muravyov, M.I. Effect of sulfide mineral content in copper-zinc concentrates on the rate of leaching of non-ferrous metals by biogenic ferric iron. Hydrometallurgy 2019, 185, 82-87. [CrossRef]

19. Arpalahti, A.; Lundström, M. The leaching behavior of minerals from a pyrrhotite-rich pentlandite ore during heap leaching. Miner. Eng. 2018, 119, 116-125. [CrossRef]

20. Watling, H.R. The bioleaching of nickel-copper sulfides. Hydrometallurgy 2008, 91, 70-88. [CrossRef] 
21. Watling, H.R. The bioleaching of sulphide minerals with emphasis on copper sulphides: A review. Hydrometallurgy 2006, 84, 81-108. [CrossRef]

22. Behera, S.K.; Manjaiah, M.; Sekar, S.; Panda, S.K.; Mavumengwana, V.; Mulaba-Bafubiandi, A.F. Optimization of microbial leaching of base metals from a South African sulfidic nickel ore concentrate by Acidithiobacillus ferrooxidans. Geomicrobiol. J. 2018, 35, 447-459. [CrossRef]

23. Muravyov, M.; Panyushkina, A.; Bulaev, A.; Fomchenko, N. Biobeneficiation of bulk copper-zinc and copper-nickel concentrates at different temperatures. Miner. Eng. 2021, 170, 107040. [CrossRef]

24. Gericke, M.; Govender, Y. Bioleaching strategies for the treatment of nickel-copper sulphide concentrates. Miner. Eng. 2011, 24, 1106-1112. [CrossRef]

25. Muravyov, M.; Panyushkina, A. Distinct roles of acidophiles in complete oxidation of high-sulfur ferric leach product of zinc sulfide concentrate. Microorganisms 2020, 8, 386. [CrossRef]

26. Panyushkina, A.; Bulaev, A.; Belyi, A.V. Unraveling the central role of sulfur-oxidizing Acidiphilium multivorum lms in industrial bioprocessing of gold-bearing sulfide concentrates. Microorganisms 2021, 9, 984. [CrossRef] [PubMed]

27. Silverman, M.P.; Lundgren, D.G. Studies on the chemoautotrophic iron bacterium Ferrobacillus ferrooxidans. I. An improved medium and a harvesting procedure for securing high cell yields. J. Bacteriol. 1959, 77, 642-647. [CrossRef] [PubMed]

28. Fadrosh, D.W.; Ma, B.; Gajer, P.; Sengamalay, N.; Ott, S.; Brotman, R.M.; Ravel, J. An improved dual-indexing approach for multiplexed 16S rRNA gene sequencing on the Illumina MiSeq platform. Microbiome 2014, 2, 1-7. [CrossRef] [PubMed]

29. Caporaso, J.G.; Kuczynski, J.; Stombaugh, J.; Bittinger, K.; Bushman, F.D.; Costello, E.K.; Fierer, N.; Pẽa, A.G.; Goodrich, J.K.; Gordon, J.I.; et al. QIIME allows analysis of high-throughput community sequencing data. Nat. Methods 2010, 7, 335-336. [CrossRef] [PubMed]

30. Quast, C.; Pruesse, E.; Yilmaz, P.; Gerken, J.; Schweer, T.; Yarza, P.; Peplies, J.; Glöckner, F.O. The SILVA ribosomal RNA gene database project: Improved data processing and web-based tools. Nucleic Acids Res. 2013, 41, D590-D596. [CrossRef] [PubMed]

31. Davis, D.G.; Jacobsen, W.R. Determination of iron and iron-aluminum mixtures by titration with EDTA. Anal. Chem. 1960, 32, 215-217. [CrossRef]

32. Filippova, N.A. Phazovy Analiz rud i Produktov ikh Pererabotki, 2nd ed.; Khimiya: Moscow, Russia, 1975.

33. Rietveld, H.M. Line profiles of neutron powder-diffraction peaks for structure refinement. Acta Cryst. 1967, 22, 151-152. [CrossRef]

34. Cruz, F.L.S.; Oliveira, V.A.; Guimarães, D.; Souza, A.D.; Leão, V.A. High-temperature bioleaching of nickel sulfides: Thermodynamic and kinetic implications. Hydrometallurgy 2010, 105, 103-109. [CrossRef]

35. Soe, K.M.; Ruan, R.; Jia, Y.; Tan, Q.; Wang, Z.; Shi, J.; Zhong, C.; Sun, H. Influence of jarosite precipitation on iron balance in heap bioleaching at monywa copper mine. J. Min. Inst. 2021, 247, 102-113. [CrossRef]

36. Hedrich, S.; Joulian, C.; Graupner, T.; Schippers, A.; Guézennec, A.-G. Enhanced chalcopyrite dissolution in stirred tank reactors by temperature increase during bioleaching. Hydrometallurgy 2018, 179, 125-131. [CrossRef]

37. Ranjbar, M.; Fazaelipoor, M.H.; Ranjbar Hamghavandi, M.; Schaffie, M.; Manafi, Z. Modeling study of the bio-dissolution of copper concentrate in a continuous bioreactors system. Miner. Eng. 2020, 153, 384. [CrossRef]

38. Liu, H.-C.; Xia, J.-L.; Nie, Z.-Y.; Liu, L.-Z.; Wang, L.; Ma, C.-Y.; Zheng, L.; Zhao, Y.-D.; Wen, W. Comparative study of S, Fe and Cu speciation transformation during chalcopyrite bioleaching by mixed mesophiles and mixed thermophiles. Miner. Eng. 2017, 106, 22-32. [CrossRef]

39. Tian, Z.; Li, H.; Wei, Q.; Qin, W.; Yang, C. Effects of redox potential on chalcopyrite leaching: An overview. Miner. Eng. 2021, 172, 107135. [CrossRef]

40. Tanne, C.; Schippers, A. Electrochemical investigation of microbially and galvanically leached chalcopyrite. Hydrometallurgy 2021, 202, 105603. [CrossRef]

41. Zhao, H.; Wang, J.; Yang, C.; Hu, M.; Gan, X.; Tao, L.; Qin, W.; Qiu, G. Effect of redox potential on bioleaching of chalcopyrite by moderately thermophilic bacteria: An emphasis on solution compositions. Hydrometallurgy 2015, 151, 141-150. [CrossRef]

42. Fu, K.; Ning, Y.; Chen, S.; Wang, Z. Bioleaching of different copper sulphide minerals and their physicochemical properties dependence. Trans. Inst. Min. Metall. Sect. C Miner. Process. Extr. Metall. 2016, 125, 1-4. [CrossRef]

43. Mason, L.J.; Rice, N.M. The adaptation of Thiobacillus ferrooxidans for the treatment of nickel-iron sulphide concentrates. Miner. Eng. 2002, 15, 795-808. [CrossRef]

44. Panyushkina, A.E.; Babenko, V.V.; Nikitina, A.S.; Selezneva, O.V.; Tsaplina, I.A.; Letarova, M.A.; Kostryukova, E.S.; Letarov, A.V. Sulfobacillus thermotolerans: New insights into resistance and metabolic capacities of acidophilic chemolithotrophs. Sci. Rep. 2019, 9. [CrossRef] [PubMed]

45. Karavaiko, G.I.; Bogdanova, T.I.; Tourova, T.P.; Kondrat'eva, T.F.; Tsaplina, I.A.; Egorova, M.A.; Krasil'nikova, E.N.; Zakharchuk, L.M. Reclassification of "Sulfobacillus thermosulfidooxidans subsp. thermotolerans" strain K1 as Alicyclobacillus tolerans sp. nov. and Sulfobacillus disulfidooxidans Dufresne et al. 1996 as Alicyclobacillus disulfidooxidans comb. nov., and emended description. Int. J. Syst. Evol. Microbiol. 2005, 55, 941-947. [CrossRef] [PubMed]

46. Panyushkina, A.E.; Tsaplina, I.A.; Grigor'eva, N.V.; Kondrat'eva, T.F. Thermoacidophilic microbial community oxidizing the gold-bearing flotation concentrate of a pyrite-arsenopyrite ore. Microbiology 2014, 83, 539-549. [CrossRef]

47. Holanda, R.; Hedrich, S.; Ňancucheo, I.; Oliveira, G.; Grail, B.M.; Johnson, D.B. Isolation and characterisation of mineral-oxidising "Acidibacillus" spp. from mine sites and geothermal environments in different global locations. Res. Microbiol. 2016, 167, 613-623. [CrossRef] [PubMed] 
48. Johnson, D.B.; Bacelar-Nicolau, P.; Okibe, N.; Thomas, A.; Hallberg, K.B. Ferrimicrobium acidiphilum gen. nov., sp. nov. and Ferrithrix thermotolerans gen. nov., sp. nov.: Heterotrophic, iron-oxidizing, extremely acidophilic actinobacteria. Int. J. Syst. Evol. Microbiol. 2009, 59, 1082-1089. [CrossRef] [PubMed]

49. Golyshina, O.V.; Lünsdorf, H.; Kublanov, I.V.; Goldenstein, N.I.; Hinrichs, K.-U.; Golyshin, P.N. The novel extremely acidophilic, cell-wall-deficient archaeon Cuniculiplasma divulgatum gen. nov., sp. nov. represents a new family, Cuniculiplasmataceae fam. nov., of the order Thermoplasmatales. Int. J. Syst. Evol. Microbiol. 2016, 66, 332-340. [CrossRef] [PubMed]

50. Bulaev, A.G.; Kanygina, A.V.; Manolov, A.I. Genome analysis of Acidiplasma sp. MBA-1, a polyextremophilic archaeon predominant in the microbial community of a bioleaching reactor. Microbiol. Russian Fed. 2017, 86, 89-95. [CrossRef] 